\title{
Implementasi pemikiran Ki Hadjar Dewantara di taman kanak-kanak
}

\author{
Eka Pamuji Rahayu ${ }^{1 *}$, S. Sugito ${ }^{1}$ \\ ${ }^{1}$ Program Pascasarjana, Universitas Negeri Yogyakarta. \\ Jalan Colombo No. 1, Karangmalang, Yogyakarta 55281, Indonesia \\ *Corresponding Author. Email: ekapamujirahayu87@gmail.com \\ Received: 14 July 2017; Revised: 24 October 2017; Accepted: 11 January 2018
}

\begin{abstract}
Abstrak
Penelitian ini bertujuan untuk mendeskripsikan tentang implementasi pemikiran Ki Hadjar Dewantara di Taman Indria Ibu Pawiyatan. Penelitian ini merupakan penelitian kualitatif dengan pendekatan studi kasus. Unit analisis Taman Indria Ibu Pawiyatan sebagai sumber informasi. Pengumpulan data dilakukan dengan observasi, wawancara, dan dokumentasi. Teknik analisis data menggunakan model Milles dan Huberman, meliputi: pengumpulan data, reduksi data, penyajian data, dan kesimpulan. Hasil penelitian menunjukkan bahwa: (1) pemikiran Ki Hadjar Dewantara yang dimplementasikan dalam proses pendidikan di Taman Indria Ibu Pawiyatan yaitu: (a) tujuan pembelajaran menuntun kodrat dan iradat anak, (b) metode pembelajaran yaitu: metode among (ing ngarso sung tulodo, ing madyo mangun karso, tut wuri handayani), sari swara, wiraga dan wirama, (c) aspek bidang pengembangan yaitu: pikiran, rasa, dan kemauan (Tri sakti), dan (d) sasaran usia yaitu mendidik anak di bawah 7 tahun. (2) Hambatan-hambatan dalam mengimplementasi pemikiran Ki Hadjar Dewantara yaitu: (a) jumlah peserta didik yang sangat minim, (b) pendidik tidak berlatar belakang dari Tamansiswa, dan (c) kurangnya komunikasi antara Majelis Ibu Pawiyatan dengan pendidik. (3) Upaya-upaya untuk meningkatkan kegiatan pembelajaran yaitu: (a) pendidik mengikuti workshop dan seminar pendidikan anak usia dini, (b) pendidik mengadakan pertemuan sarasehan, dan (c) mengaktifkan kembali komite sekolah.
\end{abstract}

Kata Kunci: implementasi, pemikiran Ki Hadjar Dewantara, Taman Indria

\section{The implementation of Ki Hadjar Dewantara's ideas in kindergarten}

This study was aimed to describe the implementation of Ki Hadjar Dewantara's ideas in the Taman Indria Ibu Pawiyatan. This study is a qualitative research using case study design. This study is a qualitative research using case study design. The analysis unit in Taman Indria Ibu Pawiyatan as the information resources. The data were obtained through observation, in depth interview, and document review. The technique of data analysis was done using Milles and Huberman models, including: Data collection, data reduction, data display, and verifying. The results show that: (1) The Implementation of Ki Hadjar Dewantara's Ideas in the learning process include: (a) the purpose of learning activities is to guide the child to kodrat and iradat, (b) methods in learning activities are among others (ing ngarso sung tulodo, ing madyo mangun karso, tut wuri handayani), sari swara, wiraga and wirama, (c) aspects of the development that is thinking, feeling, and volition (Tri sakti), and $(d)$ goal is to educate children aged under 7 years. (2) Barriers that: (a) there are only few learners, (b) educators do not have background from Tamansiswa, and (c) lack of communication between Majelis Ibu Pawiyatan and educators. (3) The efforts include: (a) educators to follow workshops, (b) seminars about early childhood education, educators held a sarasehan, and (c) reactivating the school committee.

Keywords: implementation, Ki Hadjar Dewantara's ideas, Taman Indria

How to Cite: Rahayu, E., \& Sugito, S. (2018). Implementasi pemikiran Ki Hadjar Dewantara di taman kanak-kanak.JPPM (Jurnal Pendidikan dan Pemberdayaan Masyarakat), 5(1), 19-31. doi:http://dx.doi.org/10.21831/jppm.v5i1.10704

do http://dx.doi.org/10.21831/jppm.v5i1.10704 


\section{PENDAHULUAN}

Pendidikan nasional berfungsi mengembangkan kemampuan dan membentuk watak serta peradaban bangsa yang bermartabat dalam rangka mencerdaskan kehidupan bangsa, menjadikan manusia yang beriman dan bertakwa kepada Tuhan Yang Maha Esa, berakhlak mulia, sehat, berilmu, cakap, kreatif, mandiri, dan menjadi warga negara yang bertanggung jawab. Upaya bangsa Indonesia dalam dunia pendidikan salah satunya ditandai dengan berdirinya perguruan Tamansiswa yang pertama di Yogyakarta pada tahun 1922 oleh Ki Hadjar Dewantara. Parmi (2009, p. 8) menyebutkan bahwa, konsep pendidikan nasional $\mathrm{Ki}$ Hadjar Dewantara secara filosofi mengandung makna yang sangat cocok untuk mendidik rakyat Indonesia, yang kental dengan adat ketimurannya, budaya daerahnya, kekayaan alamnya, dan keanekaragaman budaya dan suku bangsanya. Pendidikan menurut K. H.Dewantara (2013, pp. 14-15) berarti daya upaya untuk memajukan bertumbuhnya budi pekerti (kekuatan batin, karakter), pikiran (intellect) dan tubuh anak, dalam pengertian Tamansiswa tidak dipisahpisahkan agar dapat memajukan kesempurnaan hidup yakni kehidupan dan penghidupan harus selaras dengan dunianya.

Sejarah pendidikan nasional di Indonesia ditandai dengan lahirnya Tamansiswa berwujud suatu lembaga pendidikan yang menyelenggarakan berbagai perguruan untuk menampung anak-anak rakyat Indonesia yang memerlukan sekolah, karena pendidikan pada masa itu merupakan alat perjuangan bangsa Indonesia untuk bangkit dari kebodohan, dengan pendidikan pula rakyat Indonesia berhasil merdeka pada tahun 1945. Adapaun jenjang pendidikan yang terdapat di perguruan Tamansiswa yaitu Taman Indria, Taman Muda, Taman Dewasa, Taman Madya, Taman Sarjana, Taman Guru dan Taman Karya. (K. H. Dewantara, 1959, p. 5) menyebutkan berdirinya perguruan nasional Tamansiswa di Yogyakarta pada tanggal 3 Juli 1922, dimulai dengan dibukanya pendidikan bagi anakanak kecil di bawah umur 7 tahun, pendidikan tersebut diberi nama "Taman Lare" atau
"Taman Anak", disamping itu kadang-kadang digunakan juga nama penjelasannya "Sekolah Frobel Nasional" atau "Kindergarten". Ki Hadjar Dewantara memiliki konsep sendiri terkait Taman Indria walaupun konsepsi beliu terlahir atas dasar teori Frobel dan Montessori. Pemikiran dari ketiga tokoh tersebut memiliki perbedaan-perbedaan yang ada diantara adalah mengenai isi serta caranya melaksanakan pendidikan kanakkanak tersebut (K. H. Dewantara, 2013, p. 276). Frobel memberi kebebasan yang diatur secara tertib, Montessori membebaskan kanak-kanak seakan-akan tak terbatas, sedangkan Ki Hadjar Dewantara bersemboyan Tut wuri handayani, yakni memberi kebebasan yang luas, selama tidak ada bahaya yang mengancam anak-anak. Dimana pada usia dini terdapat masa keemasan (golden age) bagi pertumbuhan dan perkembangan anak (Nuryanto \& Izzaty, 2016, p. 76). Sehingga dapat dipahami bahwa pendidikan untuk anak-anak memang sangat dibutuhkan sejak anak berusia dini, hal tersebut tujuannya agar anak-anak mendapatkan tuntunan dalam kehidupannya, agar segala anak kebutuhan anak terpenuhi sesuai kodarat dan iradatnya sebagai manusia dan agar anakanak mendapatkan pengetahuan yang bermanfaat bagi dirinya.

Taman Indria adalah Taman Kanakkanak nasional pertama yang ada di Indonesia, dan merupakan Taman Kanak-kanak terbesar pada zamannya. Perkembangannya terlihat dengan keberhasilannya membuka cabang diseluruh Indonesia, dan hingga saat ini Taman Indria masih ada, namun eksistensinya mulai berkurang diseluruh Indonesia. Hal tersebut disebabkan karena muncul berbagai lembaga pendidikan di Indonesia yang menawarkan banyak pilihanpilihan bagi rakyatnya. Dalam perkembangan Tamansiswa banyak terjadi pasang surut, sehingga berdampak pada semua jenjang pendidikan yang berada didalamnya terutama jenjang Taman Kanak-kanak. Hasil penelitian Parmi (2009, p. 9) menyebutkan bahwa konsep-konsep Ki Hadjar Dewantara tentang pendidikan dan ajaran Tamansiswa sangat harum, namun eksistensi konsep pendidikannya di dunia pendidikan nasional 


\section{JPPM (Jurnal Pendidikan dan Pemberdayaan Masyarakat), 5 (1), 2018 - 21}

Eka Pamuji Rahayu, S. Sugito

kurang nampak, bahkan semakin meredup, dan nampak semakin terus menurun.

Adapun konsep-konsep pemikiran Ki Hadjar Dewantara yang sangat popular yaitu sistem pendidikannya menggunakan sistem among, kegiatan pembelajarannya memadukan antara kegiatan fisik, perasaan, dan pikiran. Parmi (2009, p. 369), secara internal penyelenggaraan pendidikan di lingkungan Tamansiswa mengalami kemunduran, gaungnya semakin tidak terdengar, bahkan mengalami berbagai kesulitan serius. Hal tersebut membuktikan bahwa eksistensi konsep pendidikan Ki Hajar Dewantara di dunia pendidikan nasional di Taman Indria juga semakin menurun. Disamping itu hasil penelitian Parmi (2009, p. 370) menyebutkan keadaan jumlah murid Tamansiswa di seluruh Indonesia pada 5 tahun terakhir sebagai berikut; (1) Tahun 2001-2002 jumlah muridnya 89.223 orang, (2) Tahun 2002-2003 jumlah muridnya 68. 916 orang, (3) Tahun 2003-2004 jumlah muridnya 40. 241 orang, (4) Tahun 2004-2005 jumlah muridnya 44.948 orang dan (5) Tahun 2005-2006 jumlah muridnya 29. 963 orang. Data peserta didik dari dokumen Taman Indria juga menunjukkan penurunan jumlah peserta didik selama 5 tahun terakhir, yaitu: tahun 2012 jumlah murid 32 orang anak, tahun 2013 jumlah murid 27 orang anak, tahun 2014 jumlah murid 21 orang anak, tahun 2014 jumlah murid 23 anak dan tahun 2015 jumlah murid 15 orang anak. Banyak faktor yang menyebabkan Tamansiswa saat ini mengalami kemunduran. Parmi (2009, p. 374), memaparkan salah satu faktornya adalah Tamansiswa kalah bersaing dengan sekolahsekolah negeri, dan guru-guru sebagian besar di Tamansiswa belum PNS, akhirnya kalau guru tersebut lulus seleksi PNS, maka mereka akan pindah ke sekolah lain. hal tersebut membuktikan bahwa perkembangan Taman Indria saat ini juga kalah saing dengan Taman Kanak-kanak lainnya, dan pendidik di Taman Indria juga sering berganti-ganti sehingga berpengaruh terhadap proses belajar mengajar. Akibatnya pembelajarannya kurang optimal dan berpengaruh terhadap motivasi belajar siswa.

\section{METODE}

Jenis penelitian yang digunakan adalah penelitian kualitatif. Adapun pendekatan yang digunakan adalah pendekatan studi kasus. Ulfatin (2013, p. 49) yaitu suatu metode penyelidikan secara langsung dengan latar belakang yang alamiah dan memusatkan perhatian pada suatu peristiwa secara insentif dan rinci. Dalam penelitian ini peneliti akan melihat secara langsung implementasi pemikiran Ki Hadjar Dewantara di Taman Indria Ibu Pawiyatan, yang merupakan sekolah Taman Kanak-kanak Nasional pertama yang didirikan oleh Ki Hadjar Dewantara yang masih ada hingga saat ini.

Setting penelitian ini adalah di Taman Indria Ibu Pawiyatan Yogyakarta. Alasan pemilihan lokasi di tempat ini dengan pertimbangan bahwa Taman Indria Ibu Pawiyatan merupakan sekolah Taman Kanak-kanak yang bersejarah dan Taman Kanak-kanak nasional pertama yang didirikan oleh pahlawan pendidikan Ki Hadjar Dewantara pada tahun 1922 serta telah terakreditasi dengan nilai A. Pemilihan Taman Indria ini sebagai setting penelitian karena belum pernah ada peneliti lain yang meneliti tentang implementasi pemikiran Ki Hadjar Dewantara di Taman Indria Ibu Pawiyatan.

Unit analisis yang menjadi sasaran penelitian ini adalah Majelis Ibu Pawiyatan, kepala sekolah, pendidik, dan orang tua di Taman Indria Ibu Pawiyatan.

Sumber pengumpulan menggunakan sumber primer dan sumber sekunder. Dalam penelitian ini data primer diperoleh langsung dari subjek (Majelis Ibu Pawiyatan, kepala sekolah, pendidik, dan orang tua). Adapun sumber data sekunder dalam penelitian ini adalah dokumen-dokumen atau bahan kepustakaan yang berkaitan dengan masalah penelitian ini seperti buku-buku karangan Ki Hadjar Dewantara dan bukubuku penunjang lainnya terkait filosofi pendidikan Ki Hadjar Dewantara.

Teknik pengumpulan data dilakukan dengan observasi, wawancara dan dokumentasi. Adapun yang diamati dalam penelitian ini adalah kesesuaian antara pemikiran $\mathrm{Ki}$ 
Hadjar Dewantara dengan situasi keadaan di lapangan, yang terdiri dari tempat, pelaku dan aktivitas.

Tempat yang diobservasi di lakukan di kelas dan di lingkungan sekolah. Pelaku yang diobservasi ialah kepala sekolah, pendidik, dan orang tua siswa yang berada di Taman Indria Ibu Pawitayatan Yogyakarta. Aktivitas yang diobservasi meliputi perencanaan, perencanaan pembelajaran, proses pembelajaran, evaluasi pembelajaran, serta peran kepala sekolah, pendidik, dan orang tua dalam partisipasinya meningkatkan seluruh aspek pendidikan di Taman Indria, selanjutnya, Instrumen pembantu yang digunakan ialah catatan lapangan.

Pengumpulan data juga dilakukan dengan interview atau wawancara. Wawancara digunakan untuk memperoleh informasi dan penjelasan dari implementasi pemikiran $\mathrm{Ki}$ Hadjar Dewantara di Taman Indria Ibu Pawiyatan, meliputi: perencanaan perencanaan pembelajaran, proses pembelajaran, evaluasi pembelajaran, serta peran kepala sekolah, pendidik, orang tua dan masyarakat dalam partisipasinya meningkatkan seluruh aspek pendidikan di Taman Indria, selanjutnya instrumen pembantu dalam wawancara ini ialah pedoman wawancara. Studi dokumen merupakan pelengkap dari penggunaan metode observasi dan wawancara dalam penelitian kualitatif.

Teknik keabsahan data menggunakan triangulasi sumber, triangulasi teknik pengumpulan data, dan waktu. Triangulasi sumber adalah untuk menguji kredibilitas data dilakukan dengan cara mengecek data yang telah diperoleh melalui beberapa sumber Triangulasi teknik yaitu dilakukan dengan cara mengecek data kepada sumber yang sama namun dengan teknik yang berbeda. Mengecek kesesuaian data yang diperoleh dengan lebih dari satu metode atau teknik pengumpulan data. Triangulasi waktu yaitu data yang dikumpulan dengan hasil wawancara, observasi atau teknik waktu yang berbeda, bila hasil penelitian menghasilkan data yang berbeda maka dilakukan secara berulang-ulang sehingga sampai ditemukan kepastian datanya.

Analisis data dalam penelitian ini menggunakan analisis data deskriptif kuali- tatif yang bertujuan untuk menggambarkan, meringkaskan berbagai kondisi, berbagai situasi, atau berbagai fenomena realitas itu ke permukaan sebagai suatu ciri, karakter, sifat, model, tanda, atau gambaran tentang kondisi, situasi, ataupun fenomena tertentu. Kemudian langkah-langkah analisis data menggunakan model Milles and Huberman yaitu: (1) mengumpulkan data, (2) reduksi data, (3) penyajian data, (4) kesimpulan.

\section{HASIL DAN PEMBAHASAN}

\section{Implementasi Pemikiran Ki Hadjar Dewantara dalam Pembelajaran di Taman Indria Ibu Pawiyatan}

Taman Indria Ibu Pawiyatan merupakan Taman Kanak-kanak nasional pertama yang berdiri pada tahun 1922 oleh Ki Hadjar Dewantara. Adapun kegiatan pembelajaran di Taman Indria Ibu Pawiayan berdasarkan hasil observasi, wawancara dan dukumen bertujuan untuk: (1) membantu anak didik mengembangkan berbagai potensi baik psikis maupun fisik yang meliputi moral dan nilai-nilai agama, sosial emosional, kognitif, bahasa, fisik, motorik, kemandirian dan seni untuk siap memasuki pendidikan dasar. Hal tersebut selaras dengan pemikiran Dewantara (1959, p. 14) Mulai umur 3 sampai 5 tahun nampaklah tri sakti (pikiran, rasa dan kemauan). (2) Melalui metode among, membimbing dengan cara asih, asah, asuh kepada peserta didik untuk dipengaruhi sehingga terbentuk manusia yang beriman dan bertakwa kepada Tuhan Yang Maha Esa, merdeka lahir bathin, luhur akal budinya, cerdas dan berketerampilan, serta sehat jasmani dan rohaninya untuk menjadi anggota masyarakat yang mandiri dan bertanggung jawab atas kesejahteraan bangsa, tanah air, serta manusia pada umumnya, tujuan tersebut selaras dengan pemikiran K. $\mathrm{H}$. Dewantara (2013, p. 20) yang menyebutkan bahwa pendidikan merupakan tuntunan di dalam hidup tumbuhnya anak-anak, dengan menuntun segala kekuatan kodrat yang ada pada anak, agar mencapai keselamatan dan kebahagiaan yang setinggi-tingginya. Serta menuntun budipekerti, watak atau karakter yaitu bersatunya gerak pikiran, perasaan dan kehendak atau kemauan yang menimbulkan 


\section{JPPM (Jurnal Pendidikan dan Pemberdayaan Masyarakat), 5 (1), 2018 - 23}

Eka Pamuji Rahayu, S. Sugito

tenaga, dengan adanya budipekerti manusia memiliki kepribadian yang mandiri, inilah manusia yang beradab (K. H. Dewantara, 2013, p. 25).

Anak merupakan anugerah dari Tuhan yang sangat dinanti kehadirannya, anak akan menjadi aset berharga jika sedini mungkin disiapkan dan diberikan segala kebutuhannya. Adapun kebutuhan anak yang paling mendasar selain nutrisi dan kasih sayang dari keluarga, anak juga butuh pendidikan. Taman Indria Ibu Pawiyatan merupakan salah satu lembaga pendidikan anak usia dini. Berdirinya Taman Indria Ibu Pawiyatan sejak tahun 1922 oleh Ki Hadjar Dewantara di perguruan Tamansiswa menandai bahwa anak-anak adalah titah (mahluk) Tuhan, dan dalam usaha pendidikan tidak bisa meninggalkan dasar-dasar kodrat dan iradat Tuhan Tauchid (1963, p. 57), membuktikan bahwa Taman Indria Ibu Pawiyatan mengimplementasikan pemikiran Ki Hadjar Dewantara sehingga Taman Indria Ibu Pawiyatan masih bertahan hingga saat ini dengan tetap memberikan layanan pendidikan untuk anakanak.

Sasaran peserta didik di Taman Indria Ibu pawiyatan berdasarkan hasil observasi dan wawancara berkisar antara usia 4 sampai 6 tahun. Nama Ibu Pawiyatan merupakan penyebutan nama untuk pusat Tamansiswa di Yogyakarta. Oleh sebab itu ada penambahan nama Taman Indria menjadi Taman Indria Ibu Pawiyatan, agar ada pembeda antara yang di pusat dan di cabang. Hal tersebut memberi arti bahwa Taman Indria Ibu Pawiyatan benar-benar didirikan oleh Ki Hadjar Dewantara, karena tahun bedirinya sejak 1922. K. H. Dewantara (2013, p. 275) menyebutkan bahwa Taman Anak dan Taman Lare harus diganti dengan nama yang baru yaitu Taman Indria, adapun alasannya karena dipandang dari sudut psikologi, jiwa kanak-kanak di bawah umur 7 tahun masih semata-mata berada dalam periode perkembangan panca indranya. Dewantara (1959), menyatakan bahwa berdirinya perguruan nasional Tamansiswa di Yogyakarta pada tanggal 3 Juli 1922, dimulai dengan dibukanya sekolah bagi anak-anak kecil di bawah umur 7 tahun, sekolah tersebut diberi nama "Taman Lare" atau "Taman Anak", disamping itu kadang-kadang digunakan juga nama penjelasannya "Sekolah Frobel Nasional" atau "Kindergarten". Hal tersebut membuktikan Taman Indria Ibu Pawiyatan mengimplementasikan pemikiran Ki Hadjar Dewantara dengan tetap membuka pendidikan untuk anak-anak usia di bawah 7 tahun, dan saat ini Taman Indria Ibu Pawiayatan disebut pendidikan Taman Kanak-kanak pada jalur formal karena anak yang dididik usianya berkisar antara 4 hingga 6 tahun. Perubahan nama Taman Indria berubah menjadi Taman Indria Ibu Pawiyatan terjadi karena alasan yang tepat, sama halnya dengan Ki Hadjar Dewantara mengubah nama Taman Lare menjadi Taman Indria karena memang pada dasarnya Ki Hadjar Dewantara tidak ingin meniru, dan tujuannya agar memberikan identitas tersendiri untuk pendidikan anak-anak pada masa itu. Sehingga dapat dimaknai bahwa Taman Indria Ibu pawiyatan mengimplementasikan pemikiran Ki Hadjar Dewantara, yaitu memberikan layanan pendidikan berdasarkan usia anak dengan memenuhi kebutuhan anak berdasarkan kelompok usianya.

Perencanaan pembelajaran di Taman Indria Ibu Pawiyatan berdasarkan hasil observasi, wawancara dan dokumen berpedoman dari kurikulum dinas. Kurikulum yang digunakan merupakan pendekatan tematik, adapun struktur kurikulum terdiri dari bidang pengembangan pembiasaan, bidang ini berisi aspek Moral dan Nilai-nilai Agama dan aspek Sosial, Emosional dan Kemandirian. Sedangkan bidang pengembangan kemampuan dasar merupakan kegiatan yang dipersiapkan untuk meningkatkan kemampuan dan kreativitas anak sesuai dengan tahap perkembangannya, bidang ini berisi kemampuan bahasa, kognitif, fisik/motorik, dan seni. Penentuan tema yang digunakan merupakan tema yang dipetik dari kurikulum dinas yang telah tersusun dalam pembelajaran selama satu tahun. Dari kurikulum tersebut dibuatlah silabus kegiatan pembelajaran yang terdiri dari program semester, program mingguan dan program harian. Penyusunan perencanaan kegiatan pembelajaran dari pengembangan kurikulum hingga menentukan kegiatan harian oleh pendidik Taman Indria Ibu Pawiyatan 


\section{JPPM (Jurnal Pendidikan dan Pemberdayaan Masyarakat), 5 (1), 2018 - 24}

Eka Pamuji Rahayu, S. Sugito

merupakan kegiatan rutinitas pendidik dengan tujuan agar pendidik lebih siap memberikan pembelajaran kepada anak didiknya.

Hal tersebut selaras dengan pandangan Dewantara (1959, p. 28) tentang Putusan Tentang Naskah Rencana Pendidikan Tamansiswa Bagian Taman Indria yaitu (1) Perguruan untuk mendidik anak-anak di bawah umur 7 tahun, sudah sejak dijaman Belanda dengan bentuk pendidikan Frobel. (2) Pada hakekatnya, pendidikan TamanIndria sesuai dengan keadaan dan susunan masyarakat yang berlaku pada waktu itu. (3) Sesuai dengan pertumbuhan jiwa anak di bawah umur 7 tahun, tidak mungkinlah diberikan pelajaran yang mempunyai hakikat memaksa sang anak. (4) Taman Indria didirikan untuk bimbingan terhadap pertumbuhan jiwa anak, latihan indera serta jasmani, sesuai dengan periode jiwa dan perasaanya. Jadi perencanaan kegiatan pembelajaran di Taman Indria Ibu Pawiayatan dari pengembangan kurikulum hingga perencanaan kegiatan harian merupakan hasil modifikasi dari pemikiran Ki Hadjar Dewantara dan peraturan pendidikan anak usia yang berlaku saat ini.

Taman Indria Ibu Pawiyatan selalu mengikuti perubahan-perubahan kurikulum yang berlaku di Tanah air, terbukti sistem pembelajaran yang ada di Taman Indria Ibu Pawiyatan selalu berubah-berubah. Berdasarkan hasil observasi dan wawancara tahun ajaran 2015/2016 Taman Indria Ibu Pawiyatan masih menggunakan kurikulum Tingkat Satuan Pendidikan (KTSP) yang dipadukan dengan kurikulum ketamansiswaan. Tahun ajaran 2016/2017 Taman Indria telah mempersiapkan diri untuk menggunakan Kurikulum Tiga Belas (KURTILAS). Hal tersebut selaras dengan pemikiran Ki Hadjar Dewantara yang menyebutkan bahwa potensi anak didik harus dikembangkan secara menyeluruh, raga, dan jiwa, lahir batin, maka dari itu perlu adanya fleksibilitas dalam kurikulum dalam rangka mengembangkan manusia seutuhnya (Hariyadi, 1985, p. 23), oleh sebab itu Taman Indria Ibu Pawiyatan dalam menyusun perencanaan kegiatan pembelajaran di Taman Indria Ibu Pawiyatan berupaya agar mengimplementasi pemikiran Ki Hadjar Dewantara dan disesuaikan dengan perkembangan kurikulum yang berlaku saat ini.

Kegiatan pembelajaran di Taman Indria Ibu Pawiyatan berdasarkan hasil observasi dan wawancara terutama dalam proses kegiatan di dalam kelas kurang memberikan kemerdekaan pada anak. Kegiatan di dalam kelas kurang menarik minat anak, dikarenakan kegiatan-kegiatannya masih berpusat pada guru, dari kegiatan pembukaan hingga kegiatan akhir semua dalam aturan guru. hal tersebut bertentangan dengan pemikiran Ki Hadjar Dewantara yang mengatakan bahwa pendidikan yang berdasarkan perintah, hukuman dan ketertiban dianggap memperkosa batin anak, maka dari itu Ki Hadjar Dewantara menggunakan dasar tertib damai dan menjaga ketentraman batin anak dengan menjauhkan anak dari paksaan, dalam hal ini tidak harus memanjakan (Hariyadi, 1985, p.19). Berdasarkan hal tersebut, Taman Indria Ibu Pawiyatan masih berupaya agar proses kegiatan pembelajaran selaras dengan pemikiran Ki Hadjar Dewantara. Seperti berupaya dalam mengelola kegiatan pembelajaran di dalam kelas, walaupun tidak ada hukuman yang diberikan pendidik namun perintah dan dan ketertiban masih nampak, meskipun dilakukan dengan sikap yang sopan dan tutur kata yang halus.

Kegiatan pembelajaran berdasarkan hasil observasi dan wawancara masih bersumber pada Lembar Kerja Anak (LKA), baik yang terdalam dalam majalah maupun yang disiapkan pendidik. Terkadang buku dan alat tulis juga digunakan ketika anakanak belajar menulis huruf. Padahal Ki Hadjar Dewantara menentang pendidikan yang hanya mementingkan intelektualisme yang dianggap hanya mengembangkan aspek kecerdasan (Hariyadi, 1985, p. 24). Sehingga dapat dimaknai bahwa Taman Indria Ibu Pawiyatan dalam memberikan kegiatan pembelajaran masih berupaya agar selaras dengan pemikiran $\mathrm{Ki}$ Hadjar Dewantara, walaupun masih memberikan pembelajaran bersifat kontekstual namun pendidik tidak memaksakan anak-anak melakukan hingga selesai, jika anak bosan 
anak dapat memilih kegiatan pembelajaran yang lainnya.

Kegiatan muatan lokal berdasarkan hasil observasi dan wawancara di Taman Indria Ibu Pawiyatan merupakan kegiatan khas, karena dalam kegiatan muatan lokal terdapat dolanan anak, tembang-tembang jawa dan menggunakan percakapan bahasa jawa. Adapun kegiatan dolanan dilakukan pada hari senin, untuk tembang-tembang dolanan dilakukan pada kegiatan akhir kegiatan pembelajaran sehari-hari. Pada pelaksanaan kegiatan dolanan anak yang dilakukan Taman Indria Ibu Pawiyatan masih dominan guru yang mengarahkan dan mengatur alur permainan, dan waktu bermain hanya satu jam lalu kembali lagi pada kegiatan pembelajaran lainnya. K. H. Dewantara (2013, p. 248) menyebutkan bahwa didikan yang terdapat dalam permainan anak-anak diterima oleh kanak-kanak tidak dengan paksaan atau perintah akan tetapi karena kemauan serta kesenangan anakanak sendiri untuk menerima dan mengalami segalanya, artinya permainan kanakkanak amat penting untuk mempertebal rasa kemerdekaan. Sehingga dapat dimaknai bahwa Taman Indria Ibu Pawiyatan belum sepenuhnya mengimplementasikan pemikiran Ki Hadjar Dewantara terkait kemerdekaan anak dalam bermain, karena dalam pelaksanaannya belum mengarah pada tuntutan jiwa anak, jadi hanya sebatas sudah melakukan saja, walaupun kegiatan tersebut bukan kegiatan sehari, namun Taman Indria tetap berusaha agar kegiatan-kegiatan untuk anak-anak selaras dengan pemikiran $\mathrm{Ki}$ Hadjar Dewantara yaitu melatih anak dengan kesenian budaya agar tumbuh jiwa anak menjunjung tinggi nilai-nilai kebudayaan bangsanya.

K. H. Dewantara (2013, p. 242) menyebutkan bahwa permainan anak Jawa seperti sumbar, gating, unclang mendidik anak agar seksama, cekatan, menjernihkan penglihatan dll, permainan dakon, cublak-cublak suweng, kubuk mendidik anak tentang pengertian perhitungan, dan pengiraan. Permainan gobak, trebung, raton, geritan, obrog, panahan, jamuran, dll mendidik anak kuat sehat badannya, kecekatan, keberanian, ketajaman penglihatan. Permainan mengutas bunga (meronce), menyulam daun pisang atau janur yaitu mendidik anak tabiat tertib dan teratur. K. H. Dewantara (2013, p. 296) menyebutkan juga dalam dolanan anak yaitu bersatunya gerak wirama dengan nyanyian serta cerita yang terkandung di dalam ilmu pendidikan disebut konsentrasi pelajaran itulah yang menyebabkan permainan kanak-kanak dalam hidup bangsa benar-benar bersifat kesenian yang mengandung faktor-faktor pendidikan estetik, hal mana dalam kebudayaan bangsa dianggap perlu untuk perkembangan jiwa pribadi kanak-kanak pada umumnya rasa etik. Berdasarkan hal tersebut, maka Taman Indria berusaha untuk mengadakan dan memepertahankan permainan-permainan tradsional seperti tembang dan dolanan anak, karena hal tersebut merupakan pemikiran Ki Hadjar Dewantara dalam memaknai kegiatan dolanan anak sebagai alat untuk mengembangkan jiwa, dalam mendidik estetik dan rasa etik pada anak-anak. hal tersebut selaras dengan K. H. Dewantara (2013, p. 264) mengatakan permainan kanak-kanak sebagai permulaan latihan kesenian pada umumnya, khususnya latihan suara, tari dan sandiwara, dan semua itu sebagai dasar-dasar pendidikan budi pekerti. Selain itu K. H. Dewantara (2013, p. 264) permainan kanak-kanak adalah kesenian kanak-kanak yang sesungguhnya amat sederhana bentuk dan isinya namun memenuhi syarat-syarat etis dan aestetis dengan semboyan dari natur ke arah kultur. Oleh karena itu kegiatan pembelajaran muatan lokal di Taman Indria Ibu Pawiayatan masih teteap ada walaupun waktu dan pelaksanaanya tidak sesering dahulu namun Taman Indria Ibu Pawiyatan tetap berusaha agar mengimplementasikan pemikiran Ki Hadjar Dewantara yang bersemboyan dari natur ke arah kultur.

Taman Indria Ibu Pawiyatan bersemboyan Tut wuri andayani, dan tulisan tersebut dapat ditemukan di baju seragam anak-anak dengan lambang Tamansiswa. Semboyan tersebut dapat ditemukan pula pada brosur Taman Indria Ibu Pawiyatan. K. H. Dewantara (2013, p. 276) menyebutkan bahwa Taman Indria bersemboyan Tut wuri andayani yakni memberi kebebasan luas selama tidak ada yang mengancam anak- 
anak. Oleh karena itu Taman Indria Ibu Pawiyatan masih mengimplementasikan semboyan tersebut yang merupakan hasil pemikiran Ki Hadjar Dewantara.

Metode dalam Kegiatan Pembelajaran di Taman Indria Ibu Pawiayan berdasarkan hasil observasi dan wawancara sangat bervariasi yaitu metode pembiasaan, metode keteladanan, metode ceramah, metode tanya jawab, metode observasi, metode demontrasi dan metode kunjungan. Hal tersebut selaras dengan pemikiran K. H. Dewantara (2013, p. 8o) berhubung dengan khususnya jiwa dalam tiap periode, haruslah cara mengajar atau metodenya di khususan, yaitu buat taman anak dan permulaan taman muda mengutamakan pembiasaan anak pada ketertiban dengan menjaga tingkah laku dan aturan lahir (metode wiraga), kelas tinggi taman muda hingga taman dewasa mementingkan ketertiban dan keteguhan batin yakni dengan menyempurnakan wirama. Jadi metode dalam kegiatan pembelajaran di Taman Indria telah disesuaikan dengan metode-metode kegiatan pembelajaran yang berlaku saat ini, namun Taman Indria tetap juga menggunakan metode among yaitu asah, asih, asuh dalam memperlakukan anak-anak, walaupun belum terlihat maksimal dalam pelaksanaanya, namun Taman Indria Ibu Pawiyatan berusaha agar selaras dengan pemikiran Ki Hadjar Dewantara terkait metode dalam kegiatan pembelajaran untuk anak-anak.

Metode yang digunakan memang sangat bervariasi namun dalam pelaksanaannya kegiatan pembelajaran untuk anak-anak masih berpusat pada guru, dari isi kegiatan, cara melakukan kegiatan dan masih diberikan contoh cara mengerjakannya. K. H. Dewantara (2013, p. 94) sistem among yaitu menyokong kodrat alamnya anak-anak yang dididik agar dapat mengembangkan hidupnya lahir dan batin menurut kodratnya masing-masing. Menururt Dewantara (1964, p.12) menyebutkan dua dasar pendidikan yang dinamakan sistem among yaitu; pertama kemerdekaan sebagai syarat untuk menghidupkan dan menggerakkan kekuatan lahir dan batin anak, sehingga dapat hidup merdeka (berdiri sendiri), dan kedua kodrat alam, sebagai syarat untuk mencapai kemajuan dengan secepat-cepatnya dan sebaik-baiknya menurut hukum evolusi. Penjelasan tersebut memberikan makna bahwa Taman Indria Ibu Pawiyatan mengimplementasikan pemikiran Ki Hadjar De-wantara terkait dengan metode-metode dalam kegiatan pembelajaran. Karena semua metode-metode yang digunkan oleh pendidik di Taman Indria Ibu Pawiyatan, walaupun hanya dilakukan pada saat proses kegiatan pembelajaran.

Dalam pelaksanaan kegiatan pembelajaran berdasarkan hasil observasi dan wawancara di Taman Indria Ibu Pawiayatan belum memperlihatkan bahwa pendidik merupakan orang tua bagi anak didiknya. Namun pendidik berusaha dengan pendekatan-pendekatan yang baik sehingga anak didik merasa nyaman dan tentram saat berada di lingkungan Taman Indria. Ki Hadjar Dewantara yang mempunyai konsepsi tentang metode among yaitu kata among yang berasal dari bahasa Jawa, mempunyai arti seseorang yang tugasnya ngemong atau momong, yang jiwanya penuh pengabdian. K. Suratman, (1990, p. 10) tutwuri berarti mengikuti dari belakang, tetapi tanpa melepaskan anak didik dari pengawasan "berjalan di belakang" berarti memberi kebebasan kepada anak-anak untuk melatih mencari jalan sendiri, pendidik hanya perlu koreksi yaitu bilamana anak menemukan bahaya yang tidak dapat dihindarinya dengan pikiran atau tenaga sendiri. Oleh karena itu Taman Indria Ibu Pawiyatan berusaha mengimplementasikan pemikiran Ki Hadjar Dewantara.

Selain metode among, ada pula metode sari swara dan metode wiraga untuk mendidik anak-anak Taman Indria Ibu Pawiyatan, metode sari swara digunakan untuk kegiatan tembang-tembang Jawa dan dolanan anak, sedangkan untuk metode wiraga untuk kegiatan menari. $\mathrm{K}$. $\mathrm{H}$. Dewantara (2013, p. 277) menyebutkan bahwa Metode sari swara yaitu menggabungkan lagu, sastra dan cerita yang menjadi gabungan pendidikan rasa, pikiran, dan budipekerti. K. H. Dewantara (2013, p. 81) mengatakan bahwa taman anak masa wiraga harus mengajarkan permainan dan olah raga dengan nyanyian anak-anak dan tari (pemeliharaan 
badan secara ritmis), nyanyian rakyat (tembang gending tanah jawa), menggambar corak dan warna, kerajinan tangan (menyulam, daun pisang, merangkai bunga, menyulam janur dsb), itu semua latihan panca indera dihubungkan dengan rasa, cerita rakyat, dongeng, dihubungkan dengan pelajaran bahasa dan lagu (metode sari swara), pelajaran mengenal keadaan tempat sekelilingnya, pelajaran ilmu alam, ilmu kodrat, ilmu bumi dan ilmu negeri (kemasyarakatan dan kenasionalan). Dari paparan tersebut dapat diketahui bahwa Taman Indria mengimplementasikan metode-metode tersebut, walaupun dengan kegiatan kesenian yang belum bervariasi.

Evaluasi yang dilakukan di Taman Indria Ibu Pawiyatan berdasarkan hasil observasi dan wawancara sejauh ini melihat hasil akhir dari pada prosesnya. Hasil akhir anak dalam setiap kegiatan pembelajaran dijadikan patokan untuk memberikan nilai, padahal seharusnya yang diperhatikan dalam mengevaluasi perkembangan anak harus melihat proses yang dilakukan anak, karena masing-masing anak memiliki perkembangan yang berbeda-beda. Di Taman Indria Ibu pawiyatan memberikan penilaian anak berdasarkan bagus dan tidaknya hasil akhir karya anak menurut pandangan pendidik, seperti beberapa kegiatan yaitu mengisi lembar kerja anak. Padahal tujuannya diberikan kegiatan untuk anak-anak adalah sebagai latihan, dan untuk mengembangkan aspek-aspek perkembangan anak, seperti beberapa pemikiran K. H. Dewantara (2013, p. 276) tentang beberapa kegiatan berikut seperti pemberian pekerjaan kepada anakanak dibiasakan menggambar, menyanyi, berbaris, bermain-main, membuat pekerjaan secara bebas dan teratur, dengan maksud agar ketertiban lahir tadi dapat mempengaruhi ketertiban batin anak. selain itu K. H. Dewantara (2013, p. 276) yang menyebutkan bahwa di dalam Taman Indria sebaiknya mendekatkan anak dengan cerita-cerita wayang, sebagai pelajaran kesusilaan, sehubungan dengan itu ada baiknya di ruanganruangan kelas diadakan hiasan-hiasan dinding yang dipakai dalam persiapan. Jadi Taman Indria Ibu Pawiyatan berupaya mengimplementasikan pemikiran Ki Hadjar
Dewantara terkait proses evaluasi dalam kegiatan pembelajaran.

Pendidik Taman Indria Ibu Pawiyatan belum melihat perkembangan anak didiknya secara menyeluruh, dalam artian untuk kegiatan-kegiatan fisik seperti senam jika anak tidak mengikuti maka anak dianggap tidak mau melakukannya, padahal kegiatan fisik anak tidak hanya dilakukan anak pada saat senam melainkan dalam kegiatankegiatan yang lainnya, yang secara tidak sadar anak-anak melakukannya itupun dapat dijadikan sumber penilaian. K. H. Dewantara (2013, p. 256) yang menyebutkan bahwa segala gerak gerik anak-anak, sikapnya, kesedihan, kesenangan, langkah lakunya, semuanya akan nampak di dalam berbagai permainannya, ini disebabkan bahwa permainan-permainan anak mengisi sepenuhnya hidup anak-anak mulai bangun tidur sampai anak tidur kembali.

Pendidik Taman Indria Ibu Pawiyatan berdasarkan hasil observasi dan wawancara kurang strategi dalam memberikan kegiatan yang seharusnya disesuaikan dengan tahapan usia anak, sehingga dalam evaluasi perkembangan anak-anak hanya dinilai sebatas kasat mata saja. Pendidik kurang menyadari apa yang menjadi kebutuhan anak-anak, padahal K. H. Dewantara (2013, p. 263) telah menyebutkan bahwa permainan anak-anak selalu mengandung pendidikan baik yang mengenai tumbuhnya jasmani maupun berkembangnya jiwa, kemajuan hidup anakanak kerena permainan-permainan berlangsung dengan baik dan sejalan dengan kodrat dan iradatnya anak-anak sesuai dengan alam yang mengelilingnya, tumbuh dari spontanitas sendiri serta terlepas dari perkosaan lahir bathin dair seorang guru. Selain itu K. H. Dewantara (2013, p. 262) telah menyebutkan bahwa sebagian besar dari permainan anak-anak disertai dengan nyanyian-nyanyian, permainan timbul karena spontanitas anak, ada yang rupa-rupanya ciptaan orang tua yang berbudi seniman, ada yang pokoknya berwujud permainan tetapi dengan diantar lagu, ada pula yang pokoknya nyanyian tetapi disertai gerak gerik berirama.

K. H. Dewantara (2013, p. 264) menyebutkan bahwa permainan anak-anak adalah kesenian anak-anak yang sungguhnya amat 
sederhana bentuk dan isinya, dan dapat dijadikan sebagai permulaan latihan kesenian pada umumnya khususnya latihan kesenian suara, tari dan sandiwara dan semuanya tersebut sebagai dasar-dasar pendidikan budi pekerti. K. H. Dewantara (2013, p. 244) permainan keolahragaan, disitu anak-anak mempergunakan kekuatan badan serta ketangkasan sikap jiwa pada umumnya dan kecakapan. K. H. Dewantara (2013, p. 244) Kecakapan mempergunakan panca indranya, menginsyafi dengan cepat dan tepat jauh dekatnya jarak, mudah menaksir tempo, berlakunya sesuatu gerakan. Jadi dapat dimengerti akan adanya hubungan erat antara latihan-latihan keolahragaan dan permainan kanak-kanak dengan bertumbuhnya budi pekerti. Berdasarkan pemaparan tersebut dapat dimaknai bahwa Taman Indria Ibu Pawiyatan berupaya mengimplementasikan pemikiran Ki Hadjar Dewantara, walaupun saat ini belum maksimal dalam menerapkan pemikiran Ki Hadjar Dewantara. Ki Hadjar Dewantara banyak memberikan pemikiran-pemikiran yang dapat dijadikan pedoman pendidik dalam menjalankan pendidikan khususnya pendidikan di Taman Indria Ibu Pawiyatan.

\section{Hambatan-Hambatan yang terjadi dalam Mengimplementasi Pemikiran Ki Hadjar Dewantara di Taman Indria Ibu Pawiyatan}

Hambatan-hambatan dalam proses kegiatan pembelajaran berdasarkan hasil observasi dan wawancara di Taman Indria Ibu Pawiayatan diantaranya adalah minimnya jumlah peserta didik yang hadir setiap hari, sarana dan prasarana penunjang pembelajaran kurang difasilitasi, dan kurangnya kreatifitas, inovasi serta strategi dalam kegiatan pembelajaran oleh pendidik dalam meningkatkan kegiatan pembelajaran. K. H. Dewantara (2013, p. 74), menyebutkan bahwa perguruan berdiri sebagai titik pusat dari persatuan ketiga pusat yakni menjadi perantararaannya keluarga dan anak-anaknya dengan masyarakat. Suratman (1985, p. 7) menyebutkan bahwa sistem pendidikan yang dikemukakan oleh Ki Hadjar Dewantara dinamakan "Sistem Tripusat" yaitu; (1) Alam keluarga, pusat pendidikan yang pertama dan yang terpenting, tugasnya mendidik budi pekerti dan laku sosial. (2) Alam perguruan, pusat pendidikan yang berkewajiban mengusahakan kecerdasan pikiran dan memberi ilmu pengetahuan dan (3) Alam pemuda, membantu pendidikan baik yang menuju kepada kecerdasan jiwa maupun budi pekerti.

Jadi pendidik, orang tua dan masyarakat yang terlibat di Taman Indria Ibu Pawiayatan berupaya mengimplementasikan pemikiran Ki Hadjar Dewantara terkait sistem pendidikan yang ada di Taman Indria Ibu Pawiayatan merupakan hasil keselaran sistem tripusat, yakni persatuan ketiganya antara keluarga, anak-anak dan masyarakat. Karena keberhasilan anak adalah dibangun berdasarkan upaya dan keselarasan ketiga komponen tersebut. Maka seluruh aspek yang ada di Taman Indria hendaknya menemukan solusi dari hambatan-hambatan seperti yang dialamai saat ini, karena seluruh komponen tersebut bekerja sama dan saling mangisi kekurangan dengan memberikan kelebihan yang dimiliki.

Tugas pamong di Taman Indria Ibu Pawiyatan harus benar-benar membimbing dan menuntun anak-anak sesuai dengan kodrat dan iradatnya anak-anak, namun yang terjadi saat ini ikatan pamong dengan anak-anak tidak seerat masa awal berdirinya Taman Indria. Hariyadi (1985, pp. 14-15) menyebutkan bahwa sistem among yang dijiwai oleh sendi hidup kekeluargaan harus menempatkan hubungan siswa dan pamong dalam suasana yang secara manusiawi sama, seorang pamong wajib memahami sifat kodrati dari masing-masing anak didiknya yang satu dengan lainnya berbeda. Hal tersebut selaras dengan pemikiran Ki Hadjar Dewantara yang menyakan bahwa guru tamansiswa disebut sebagai pamong, dimana ia harus bersikap laku among terhadap anak didiknya, sikap among artinya membantu, memelihara suasana, menciptakan iklim kondusif disertai tanggung jawab, kerelaan berkorban, penuh pengabdian dan dilandasi oleh kasih sayang dan kemanusiaan (Hariyadi, 1985, p. 14). Jadi Taman Indria Ibu Pawiyatan berupaya untuk mengimplementasikan tugas pamong sesuai dengan pemikiran Ki Hadjar Dewantara. 


\section{JPPM (Jurnal Pendidikan dan Pemberdayaan Masyarakat), 5 (1), 2018 - 29}

Eka Pamuji Rahayu, S. Sugito

Pamong sebagai pemimpin harus bersikap ing ngarsa sung tulada, ing madya mangunkarsa, tutwuri handayani, pamong harus ngerti, ngrasa, dan nglakoni (Hariyadi, 1985, p. 16). Pamong sebagai pendidik hakekatnya wajib menjadi panutan dari anak didiknya dengan memberikan teladanteladan yang positif dalam kehidupan seharihari, pamong harus konsekuen dan konsisten dalam tingkah lakunya atau satunya kata dan perbuatan (Hariyadi, 1985, p. 15). Pamong harus memberi dorongan semangat pada siswanya dalam melaksanakan tugasnya, dorongan semangat hendaknya berjalan secara wajar, tidak berlebihan, karena hal itu merupakan tuntutan Hariyadi (1985, p. 16). Hal tersebut tercermin dalam keteladan pendidik dalam berperilaku sehari-hari, dengan bertutur kata halus, bersikap santun, berkelakuan baik agar anak-anak dapat meniru dan diharapkan akan menjadi kebiasaan baik dalam kehidupan sehari-hari. Jadi berdasarkan uraian tentang pamong menurut pemikiran Ki Hadjar Dewantara dan tugas pamong saat ini di Taman Indria Ibu Pawiyatan, berupaya agar mengimplementasikan pemikiran Ki Hadjar Dewantara, walaupun saat ini belum maksimal, namun kedepannya pamong atau pendidik Taman Indria Ibu Pawiyatan bisa lebih baik dalam melakukan tugasnya sebagai pendidik. Pendidik di Taman Indria berjumlah 8 orang dengan rincian 7 pendidik wanita dan 1 pendidik laki-laki. Menurut K. H. Dewantara (2013, p. 241) di Taman anak pengajarannya adalah guru wanita, sebab dengan anak kecil rasa bathinnya (kecintaan, rasa, takut, bangga, manja) masih tertuju pada ibunya, jadi masih sehati dengan pendidik wanita.

Jadi dalam memilih pendidik di Taman Indria Ibu Pawiyatan berupaya mengimplementasikan pemikiran Ki Hadjar Dewantara, walaupun masih ada pendidik laki-laki, karena pendidik laki-laki satu-satunya di Taman Indria tersebut merupakan pelatih renang yang tugasnya melatih anak-anak untuk berenang. Dari 8 orang pendidik ada 2 orang yang merupakan alumni Taman siswa, hal tersebut memberikan makna bahwa pendidik di Taman Indria Ibu Pawiyatan dominan memiliki latar belakang pendidikan yang berbeda-beda, sehingga pembelajaran- nya yang diberikan sesuai dengan keahlian pendidik, namun dalam pembiasaan dalam ketamansiswaan kurang diimplementasikan karena pendidik-pendidik tersebut tidak mendapatkan bekal terkait konsep pendidikan di Tamansiswa.

\section{Upaya-Upaya yang Dilakukan dalam Meningkatkan Proses Kegiatan Pembelajaran di Taman Indria Ibu Pawiyatan}

Bentuk upaya Taman Indria dalam meningkatkan kondisinya saat ini agar dapat kembali lagi bersinar seperti dahulu berdasarkan hasil observasi dan wawancara yaitu: kepala sekolah beserta pendidik melakukan musyawarah secara intern, lalu melakukan sarasehan dengan mengundang berbagai pihak seperti orang tua, alumni-alumni, para pemerhati Taman Indria, dan MIP guna musyawarah untuk mencari pokok masalah dan bagaimana bentuk jalan keluar dari masalah yang dihadapi Taman Indria Ibu pawiyatan saat ini. MIP berencana untuk mengadakan pembelakan untuk pamongpamong Tamansiswa agar para pamong lebih memahami lagi isi dari Tamansiswa. Pendidik dan segenap warga Taman Indria membagi-bagikan brosur beserta formulir pendaftaran kepada orang tua yang meiliki anak di bawah tujuh tahun, dengan harapan tahun selanjutnya pesera didik akan bertambah jumlah dan program-program hasil sarasehan akan diuji coba pada tahun ajaran selanjutnya.

Dewantara (1964, p.13) juga menetapkan lima dasar atau yang biasa disebut panca dharma yang berisi; Dasar kodrat alam, hakekatnya manusia sebagai makhluk Tuhan, Dasar kemerdekaan, hak manusia untuk mengatur hidupnya sendiri, Dasar kebudayaan, membawa kebudayaan nasional ke arah kemajuan sesuai kecerdasan zaman dan kemajuan dunia. Dasar kebangsaan, bersatu dalam suka dan duka, dan dalam kehendak mencapai kebahagiaan hidup lahir batin seluruh bangsa. Dasar kemanusiaan, dharma tiap-tiap manusia yang timbul dari keluhuran akal budinya. Taman Indria berupaya mengimplementasikan pemikiran Ki Hadjar Dewantara terkait kandungan isi dari panca dharma yang merupakan dasar pendirian 


\section{JPPM (Jurnal Pendidikan dan Pemberdayaan Masyarakat), 5 (1), 2018 - 30}

Eka Pamuji Rahayu, S. Sugito

Tamansiswa sekaligus dasar dari taman Indria, jika dimaknai panca dharma butir ke tiga yaitu membawa kebudayaan nasional kearah kemajuan sesuai kecerdasan zaman dan kemajuan dunia, jelaslah bahwasannya dari MIP, kepala sekolah, guru berupaya mempersiapkan diri dengan pembekalan diri yang lebih bermanfaat demi kemajuan Taman Indria Ibu Pawiyatan. Karena setiap tahun akan ada perkembangan-perkembangan dalam dunia pendidikan sehingga orang tua di luar sana berminat memasukan anaknya ke Taman Indria dikarenakan sistem pembelajaran di Taman Indria lebih maju dan berciri khas, sehingga Taman Indria Ibu Pawiyatan tidak mengalami ketertinggalan dan mengalami krisis jumlah peserta didik seperti yang dialami saat ini.

K. H. Dewantara (2013, p. 71) menyebutkan bahwa alam keluarga merupakan pusat pendidikan yang pertama dan terpenting, karena keluarga akan selalu mempengaruhi bertumbuhnya budi pekerti dari tiap-tiap manusia. Maka dari itu, perlu adanya kerjasama antara orang tua dan Taman Indria Ibu Pawiyatan dalam mendidik anakanak agar anak-anak mendapatkan segala kebutuhannya. Banyak hal yang didapat anak di Taman Indria, namun orang tua kurang menyadari sehingga menganggap Taman Indria belum menjalankan tugasnya dalam mendidik anak-anak mereka. Padahal orang tua sebaiknya tanggap bahwa pendidik Taman Indria juga memiliki keterbatasan dan kekurangan dalam penyelenggaraan pendidikan. Jadi antara orang tua dan Taman Indria saat ini berupaya mengimplementasikan pemikiran Ki Hadjar Dewantara, walupun saat ini nampak kerenggangan diantara orang tua dan pendidik Taman Indria Ibu Pawiyatan. Namun perlahan membaik karena kegiatan-kegiatan di Taman Indria Ibu Pawiyatan banyak melibatkan orang tua. Jika orang tua memahami tugas pendidik terhadap anak-anaknya maka orang tua memiliki kepercayaan terhadap pendidik, sebaliknya jika pendidik merasa orang tua terlalu melibatkan dirinya dalam urusan di Taman Indria maka sebaiknya pendidik memberikan ruang, agar orang tua mengetahui sejauh mana perkembangan anak-anak di Taman Indria Ibu Pawiyatan.
Jadi antara pendidik dan orang tua samasama berupaya mengimplementasikan pemikiran Ki Hadjar Dewantara, agar terjalin keharmonisan diantara keduanya.

\section{SIMPULAN DAN SARAN}

\section{Simpulan}

Berdasarkan hasil penelitian dan pembahasan, maka dapat disimpulkan bahwa: (1) Implementasi pemikiran Ki Hadjar Dewantara di Taman indria Ibu Pawiyatan dalam kegiatan pembelajaran meliputi: (a) Tujuan kegiatan pembelajaran yaitu untuk menuntun kodrat dan iradat anak, menuntun budi pekerti anak, memberikan pengetahuan yang berfaedah bagi anak, mendidik anak dari natur kearah kultur. (b) Metode dalam kegiatan pembelajaran meliputi: Metode among tercermin dalam prilaku pendidik yaitu ing ngarso sung tulodo di depan memberi teladan, ing madyo mangun karso di tengah memberi semangat dan bimbingan, dan tut wuri handayani di belakang memberi dorongan, metode sari swara tercermin dalam kegiatan dolanan anak memadukan antara cerita dan lagu, metode wiraga (gerak) dan wirama (ritme) tercermin dalam kegiatan menari dan menyanyi. (c) Aspek bidang pengembangan meliputi: pikiran, rasa, dan kemauan (Tri Sakti) tercermin dalam lima aspek perkembangan anak yaitu: aspek sosial emosional, kognitif, bahasa, fisik motorik, serta moral dan nilainilai agama. (d) Sasaran usia yaitu mendidik anak di bawah 7 tahun tercermin dalam layanan pendidikan Taman Indria Ibu Pawiyatan untuk anak usia 4 sampai 6 tahun. (2) Hambatan-hambatan dalam mengimplementasikan pemikiran Ki Hadjar Dewantara di Taman Indria Ibu Pawiyatan yaitu: (a) Jumlah peserta didik yang sangat minim, (b) pendidik yang latar belakangya bukan dari Tamansiswa, dan (c) kurangnya komunikasi antara Majelis Ibu Pawiyatan dengan pendidik Taman Indria. (3) Bentuk upaya-upaya yang dilakukan dalam meningkatkan layanan di Taman Indria Ibu Pawiyatan yaitu: (a) pendidik mengikuti workshop, seminar tentang pendidikan anak usia dini, (b) pendidik mengadakan pertemuan sarasehan dengan mengundang 
JPPM (Jurnal Pendidikan dan Pemberdayaan Masyarakat), 5 (1), 2018 - 31

Eka Pamuji Rahayu, S. Sugito

alumni-alumni Taman Indria, MIP dan orang tua, dan (c) mengaktifkan kembali komite sekolah, sehingga orang tua dan pendidik mendapatkan ruang untuk berdiskusi terkait pembelajaran dan perkembangan anak-anak.

\section{Saran}

Berdasarkan kesimpulan terkait penelitian tentang implementasi pemikiran $\mathrm{Ki}$ Hadjar Dewantara di Taman Indria Ibu Pawiayatan Yogyakarta dapat dirumuskan saran-saran sebagai berikut: (1) taman Indria hendaknya tetap berusaha meningkatkan kegiatan-kegiatan yang pembelajaran yang khas sesuai dengan pemikiran-pemikiran Ki Hadjar Dewantara, dengan menata kembali kurikulum serta perangkat pembelajarannya, (2) jumlah anak didik yang minim hendaknya dijadikan motivasi untuk mengembangkan kegiatan pembelajaran yang beraneka ragam agar seluruh aspek perkembangan anak-anak dapat terstimulus sesuai dengan perkembangannya, (3) Pengurus Ibu Pawiyatan hendaknya membuat pedoman tertulis yang berisi tentang kebijakan-kebijakan terkait pendidikan di Taman Indria sehingga pendidik memiliki pedoman dalam memberikan pembelajaran sesuai dengan nilai-nilai yang diajarkan oleh Ki Hadjar Dewantara, (4) sistem-sistem seperti sistem among (kodrat alam dan kemerdekaan) dan trilogi, sistem Tri sentra atau Tri Pusat, serta Panca Dharma diterapkan dengan konsisten sehingga mencerminkan ciri khas pendidikan Ki Hadjar Dewantara.

\section{DAFTAR PUSTAKA}

Dewantara, H. (1959). Taman-indrya: Kindergarten. Yogyakarta: Madjelis
Luhur, Persatuan Taman-Siswa.

Dewantara, K. H. (2013). Karya Ki Hadjar Dewantara bagian pertama: Pendidikan. Yogyakarta: Majelis Luhur Persatuan Taman Siswa.

Hariyadi, K. (1985). Sistem among sebagai sistem pendidikan dan sistem sosial. Yogyakarta: Majelis luhur persatuan Tamansiswa.

Nuryanto, S., \& Izzaty, R. E. (2016). Peranan dongeng dalam pendidikan karakter pada taman kanak-kanak Lazuardi Kamila di Surakarta. Jurnal Pendidikan Dan Pemberdayaan Masyarakat, 3(1), 75 .

https://doi.org/10.21831/jppm.v3i1.8063

Parmi, I. T. (2009). Refleksi konsep pendidikan Ki Hadjar Dewantara yang berwawasan nasional menuju integrasi nasional: sebuah pemikiran pendekatan historis kultural. Universitas Negeri Yogyakarta.

Suratman, D. (1985). Ki Hadjar Dewantara. Jakarta: Departemen Pendidikan dan Kebudayaan Republik Indonesia.

Suratman, K. (1990). Penerapan tut wuri handayani dalam etika profesi guru. Yogyakarta: Majelis Luhur Persatuan Tamansiswa.

Tauchid, M. (1963). Perdjuangan dan adjaran hidup Ki Hadjar Dewantara. Yogyakarta: Madjelis Luhur Taman Siswa.

Ulfatin, N. (2013). Metode Penelitian Kualitatif di Bidang Pendidikan: Teori dan Aplikasinya. Malang: Bayumedia Publishing. 